Journal of Advanced Research in Fluid Mechanics and Thermal Sciences

Journal homepage: www.akademiabaru.com/arfmts.html ISSN: 2289-7879

\title{
Determination of Limiting Heat Flux for The Inception of Nucleate Boiling Regime for Crude Oils
}

\author{
Obaid ur Rehman ${ }^{1}$, Marappa Gounder Ramasamy ${ }^{1,}$, , Nor Erniza M Rozali ${ }^{1}$, Umesh B. Deshannavar ${ }^{2}$ \\ Department of Chemical Engineering, Universiti Teknologi PETRONAS, 32610 Seri Iskandar, Perak, Malaysia \\ Chemical Engineering Department, KLE Dr. M. S. Sheshgiri College of Engineering and Technology, Udyambag, Belgaum 590008, Karnataka, \\ India
}

\section{ARTICLE INFO}

\section{Article history:}

Received 11 April 2021

Received in revised form 6 July 2021

Accepted 10 July 2021

Available online 9 August 2021

\section{Keywords:}

Crude oil fouling; limiting heat flux; forced convective heat transfer; nucleate boiling; prediction model

\section{ABSTRACT}

Finding the limiting heat flux above which nucleate boiling starts and below which forced convective heat transfer exists is a crucial task for the accuracy of results from crude oil fouling tests. In this study, crude oils from two sources were tested at bulk temperatures of 100,120 and $140{ }^{\circ} \mathrm{C}$ and different velocities. Heat transfer coefficient increased gradually with bulk temperature indicated lowering of the viscosity at high temperatures which promoted turbulence and enhanced heat transfer. The velocity effects were similar to that of bulk temperatures on maximum heat transfer coefficient while less heat flux was required to achieve the same surface temperature at lower velocities. Deshannavar and Ramasamy's model to predict maximum heat flux was compared with experimental results and a poor estimation was observed for the crude oils tested.

\section{Introduction}

Heat exchanger train plays an essential role in refineries by increasing the temperature of crude oil to meet the operational needs of refinery. The main problem of heat exchanger operation is the development of fouling layer on the surface of heat transfer, which decreases its thermal efficiency. Fouling has been considered as long-standing problem in refineries, waste water treatment [1] and dairy processing [2] plants and it has a high impact on the operational efficiency, economic growth, and environmental liability. Due to its complex nature, especially in refinery pre-heat trains, the fouling problem is still one of the main concerns in the research society which needs to be solved. Several studies have been done to study the fouling phenomenon on lab apparatus as well as actual heat exchanger trains in refineries. Generally, fouling takes place in forced convective regime in industrial heat exchangers.

Threshold fouling is a state of zero net fouling rate which could be achieved by manipulating the film temperature and bulk velocity. Several researchers developed semi-empirical and empirical models for predicting the threshold fouling conditions [3-8]. In many studies [6, 9-14], different

\footnotetext{
* Corresponding author.

E-mail address: marappagounder@utp.edu.my
}

https://doi.org/10.37934/arfmts.85.2.115127 
experimental setups were employed to determine the fouling behavior of crude oils. As the foulant particles deposition is highly dependent upon fluid velocity [15] and temperature, most of the research studies are carried out at high heat flux and low velocities to induce fast development of the fouling layer in the laboratory apparatus. Sometimes the operational conditions are so escalated that the heat transfer process occurs beyond the forced convective regime. The nucleate boiling condition is described by the formation of small bubbles on heat transfer which leads to fluid mixing near the surface resulting in the increased heat transfer coefficient. This phenomenon can cause a false calculation of the fouling rate [16]. It is of high importance to maintain the fouling experiment in the operating conditions which do not lead to nucleate boiling and to estimate the maximum flux above which boiling starts. Several studies showed the occurrence of boiling during fouling experiments $[17,18]$. Ishiyama and Pugh [19] analyzed the impact of boiling condition on the heat exchanger network. They showed that it adversely affected the performance of pump and heat exchangers and forced the pump to reach its hydraulic limits which caused low throughput and increased fouling. Harris [20] found that extra power and pressure were maintained at the boiling condition of light crude oil to achieve the same surface temperature condition when using heavier crude oil without boiling. These results suggested that flashing can reduce the boiling and fouling was achieved at lower wall temperatures. Deshannavar and Ramasamy [21] developed a model to predict the limiting heat flux above which nucleate boiling would be induced for some crude oils. They suggested that the maximum heat flux, qmax, can be calculated by incorporating the temperature from the boiling point curve at 50 vol\% cumulative recovery $\left(T_{b p 0.5}\right)$ in the convective heat transfer equation as shown below:

$q_{\max }=h\left(T_{b p 0.5}-T_{b}\right)$

where $T_{b}$ and $h$ are bulk temperature of the fluid and heat transfer coefficient, respectively. They found that the Prandtl analogy showed better predictability for heat transfer coefficient with $\pm 12 \%$ relative error. The relative percentage error for the maximum flux estimation from the model was $\pm 10 \%$.

In this paper, we carried out a study to estimate the minimum heat flux above which nucleate boiling regime persists. Two types of crude oils having different densities at varying bulk temperatures and velocities were tested. The validation of Deshannavar and Ramasamy's model was carried out to show its predictability for the crude oils at varying operating conditions.

\section{Methodology}

\subsection{Experimental Setup}

A small-scale recirculation flow equipment with an annular flow was employed to conduct the experiments, as shown in Figure 1. The equipment is installed with a $60 \mathrm{~L}$ capacity feed tank fitted with three $5 \mathrm{~kW}$ external band heaters to achieve the desired bulk temperature. An internal heating coil is placed to maintain bulk temperature by circulating hot thermal oil. Fouling takes place at an annular test section which consists of fouling probe placed inside a pipe. FIREROD cartridge heaters are installed in the fouling probes. K-type thermocouples are used for the temperature measurement of heaters $\left(T_{h}\right)$. A constant flow is maintained inside the annular section using PID controllers while $\mathrm{PI}$ controllers are used to control the heat flux. 


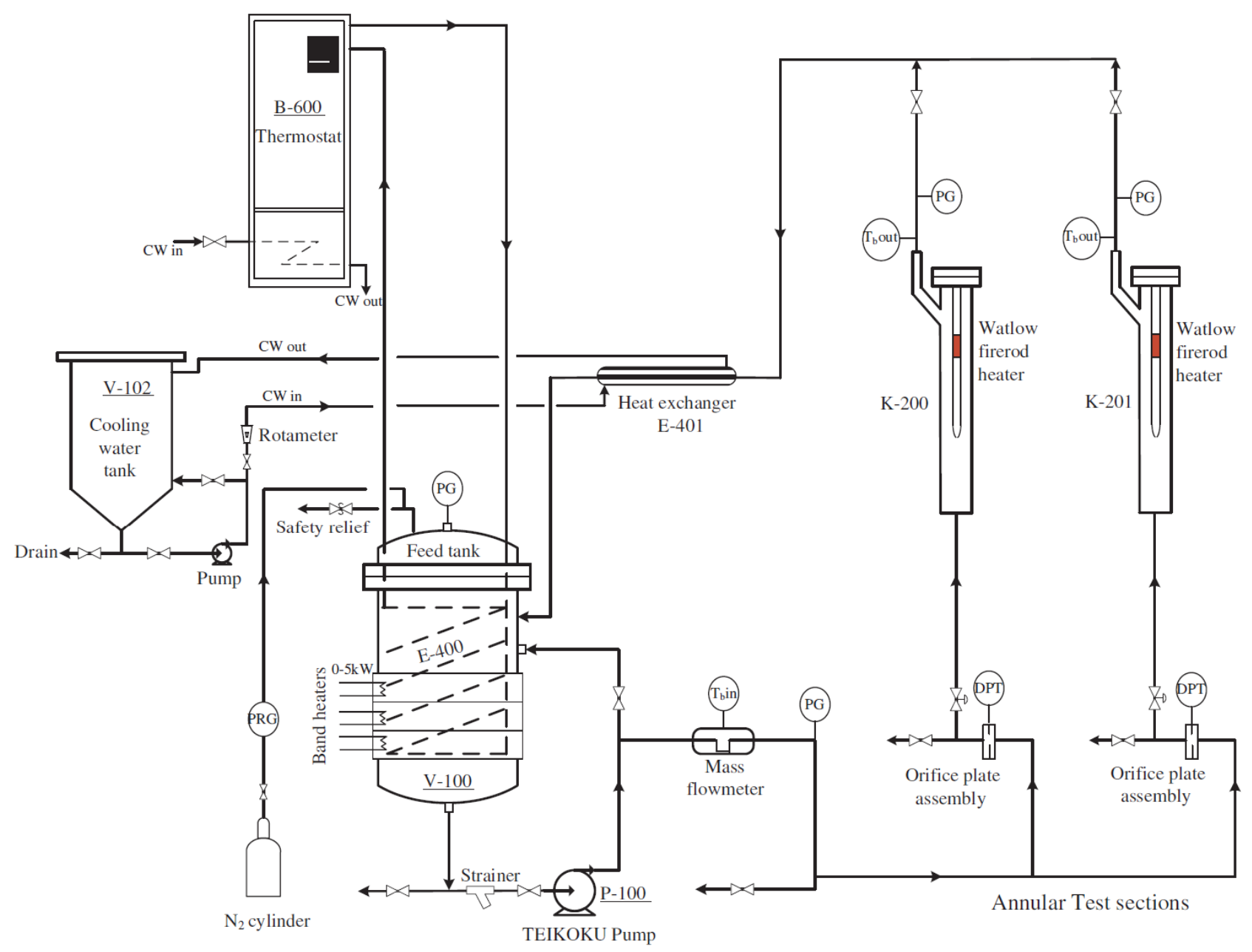

Fig. 1. Schematic of Annular Flow Fouling Research Unit (AFFRU)

\subsection{Experimental Procedure}

Experiments were performed at different bulk temperatures and velocities to develop a boiling curve. At first, the feed tank is filled with crude oil and pressurized up to 50 bar using nitrogen gas. The desired temperature is achieved by circulating the thermal oil in the heating coils and band heaters. After maintaining the velocity and bulk temperatures at a desired value, the test section was heated at constant heat flux using cartridge heaters. The heat flux, $q$, is gradually increased, and corresponding heater temperatures, $T_{h}$, are noted when the values are stable for each power output. To determine the surface temperature the value of thermal wall resistance, $R_{w}$, is estimated suing the Wilson plot. The Wilson was developed by plotting the inverse value of heat transfer coefficient, $h$, against $v^{-0.8}$ which led to the formation of straight line. The y-intercept is read from the plot which represents the value of $R_{w}$. A linear relationship was found between $R_{w}$ and $T_{h}$ which can be expressed as

$$
R_{w}=a+b T_{h}
$$

The values of the constants $a$ and $b$ are shown in Table 1 . 
Table 1

Values of constants used in Equation 2

\begin{tabular}{lll}
\hline Thermocouples & $\mathrm{a}$ & $\mathrm{b}$ \\
\hline 1 & 0.34 & 0.0014 \\
2 & 0.29 & 0.0014 \\
\hline
\end{tabular}

The values of $R_{w}$ for thermocouples 1 and 2 at $T_{h}=250{ }^{\circ} \mathrm{C}$ is $0.685 \mathrm{~m}^{2} \cdot \mathrm{K} / \mathrm{kW}$ and $0.639 \mathrm{~m}^{2} \cdot \mathrm{K} / \mathrm{kW}$, respectively. The surface temperature, $T_{s}$, for each corresponding value of $T_{h}$ was calculated using the following equation

$T_{s}=T_{h}-\left(R_{w} \times q\right)$

The boiling curves were obtained by plotting the difference of surface and bulk temperatures, $\left(T_{s}-T_{b}\right)$, vs. heat flux, $q$ and heat transfer coefficient, $h$. The values of $q_{\max }$ were read from $q$ vs $\left(T_{s}-T_{b}\right)$ graphs.

\subsection{Crude Oil Properties}

The properties of crude oils, referred here as crude oil A and B, are presented in Table 2.

Table 2

Assay of the crude oils

\begin{tabular}{llll}
\hline Properties & \multirow{2}{*}{ Units } & \multicolumn{2}{l}{ Crude Oils } \\
\cline { 3 - 4 } & & $\mathrm{A}$ & $\mathrm{B}$ \\
\hline Asphaltenes content & \%mass & 0.0011 & 1.4313 \\
API gravity & degrees & 37.9 & 32.7 \\
Viscosity @ 40C & cSt & 2.496 & 4.901 \\
Total sulphur & wt\% & 0.0621 & 1.9117 \\
Sodium (Na) & ppm & 1.73 & 0.650 \\
Vanadium (V) & ppm & 0.27 & 15.441 \\
Mercury (Hg) & ppb & 9.77 & 2.52 \\
Nickel (Ni) & ppm & 0.32 & 4.265 \\
Iron (Fe) & ppm & - & 1.355 \\
Copper (Cu) & ppm & - & 0.112 \\
\hline
\end{tabular}

3. Results

3.1 Crude Oil A

\subsubsection{Effect of bulk temperature}

Boiling curves were developed for crude oil A to find the minimum heat flux required to induced nucleate boiling at different bulk temperatures. The surface temperatures, $T_{s}$, were estimated for corresponding heater temperatures, $T_{h}$ at different values of heat flux. The heat flux, $q$, was plotted against the difference between surface and bulk temperatures, $\left(T_{s}-T_{b}\right)$, at $100,120 \& 140{ }^{\circ} \mathrm{C}$ of bulk temperature and $0.4 \mathrm{~m} / \mathrm{s}$ of velocity as shown in Figure 2 . The $T_{s}-T_{b}$ value increased linearly with the heat flux, $q$, up to threshold values of $99.6,87.6 \& 70.57^{\circ} \mathrm{C}$ at bulk temperatures of $100,120 \& 140$ ${ }^{\circ} \mathrm{C}$, respectively. After the threshold limit, the $\left(T_{s}-T_{b}\right)$ value became independent of the heat flux.

The heat transfer coefficient was estimated using the experimental data and a graph was developed by plotting against $\left(T_{s}-T_{b}\right)$ as depicted in Figure 3. Initially, the heat transfer coefficient increased gradually which indicated lowering of the viscosity at high temperatures which promoted turbulence and enhanced heat transfer. Beyond the threshold limit the slope suddenly became very 
steeper which represented the inception of nucleate boiling. the heat flux at threshold points were found to be $75.1,76.4$, and $65.4 \mathrm{~kW} / \mathrm{m}^{2}$ for bulk temperatures of 100,120 , and $140{ }^{\circ} \mathrm{C}$, respectively.

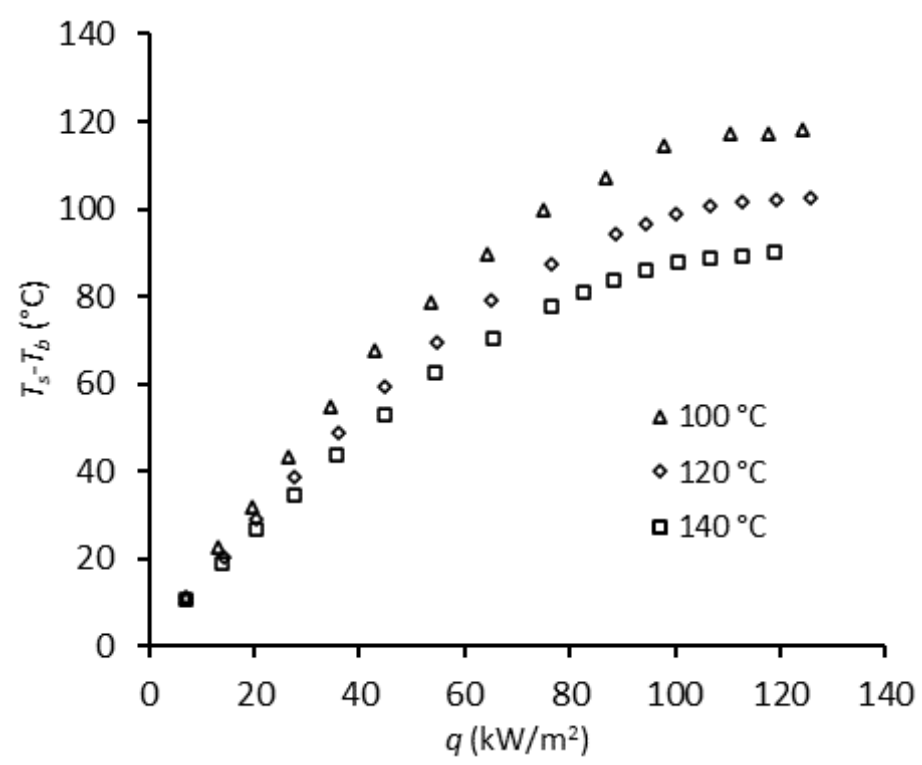

Fig. 2. Boiling curve to determine $q_{\max }$ and $\left(T_{s}-T_{b}\right)_{\max }$ at different bulk temperatures for crude oil $A$ at velocity of $0.4 \mathrm{~m} / \mathrm{s}$ and pressure of 50 bar

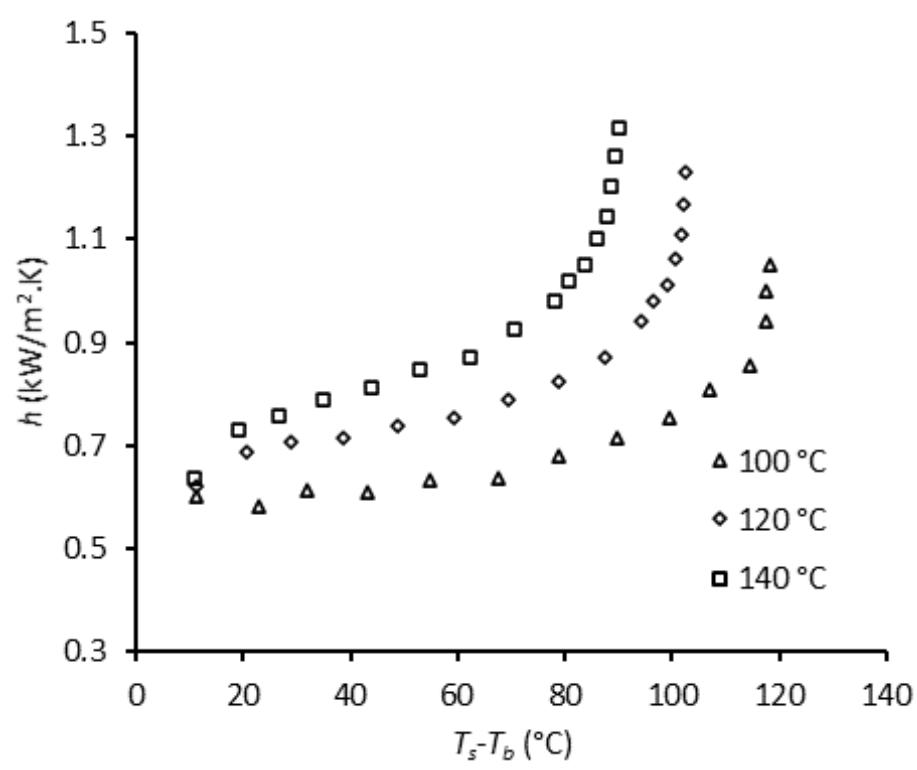

Fig. 3. Boiling curve to determine $h_{\max }$ at different bulk temperatures for crude oil $A$ at velocity of $0.4 \mathrm{~m} / \mathrm{s}$ and pressure of 50 bar

\subsubsection{Effect of velocity}

To determine the effect of velocity on the threshold values of heat flux, boiling curves were compared at different velocities with same bulk temperature of $100^{\circ} \mathrm{C}$ as shown in Figure 4 and 5 . The heat transfer coefficient gently increased in the region before the inception of nucleate boiling, as shown in Figure 4, which showed the effect of lowering viscosity and improved heat transfer. The threshold points were determined at graph with values of $99.6,97.5,92.7$, and $89{ }^{\circ} \mathrm{C}\left(T_{s}-T_{b}\right)$ at 0.4 , 
$0.5,0.6$, and $0.7 \mathrm{~m} / \mathrm{s}$ of velocities, respectively. The point of drastic change in the slope depicted the onset of nucleate boiling. The corresponding values for heat flux were determined in Figure 5. A notable increase in values of $h_{\max }$ and $q_{\max }$ can be seen with increasing velocities [22].

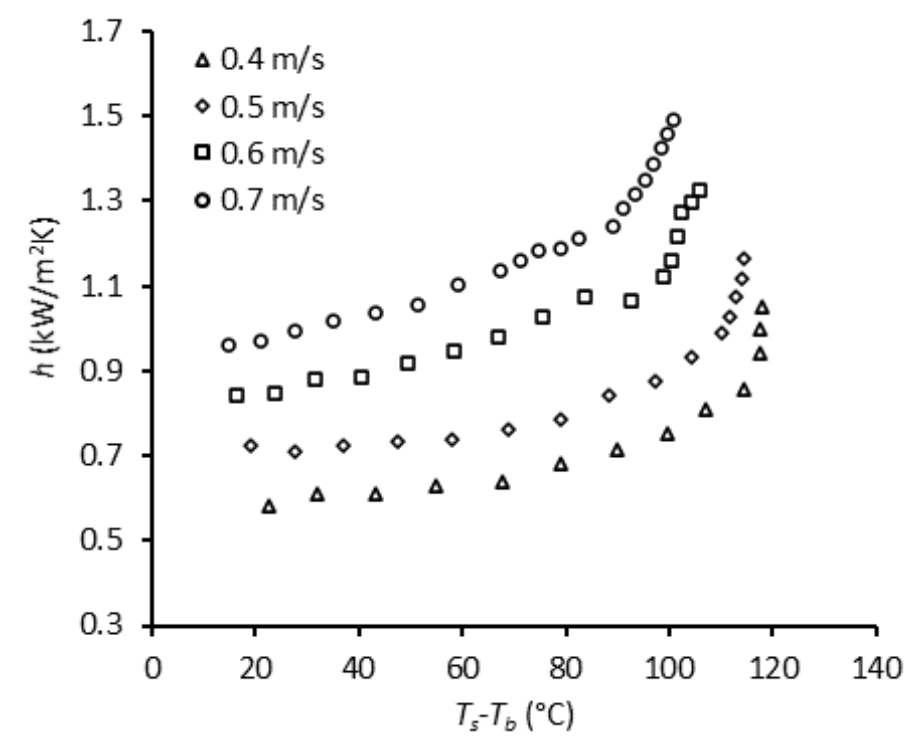

Fig. 4. Velocity effect on $h_{\max }$ for crude oil $\mathrm{A}$ at bulk temperature of $100{ }^{\circ} \mathrm{C}$ and pressure of 50 bar

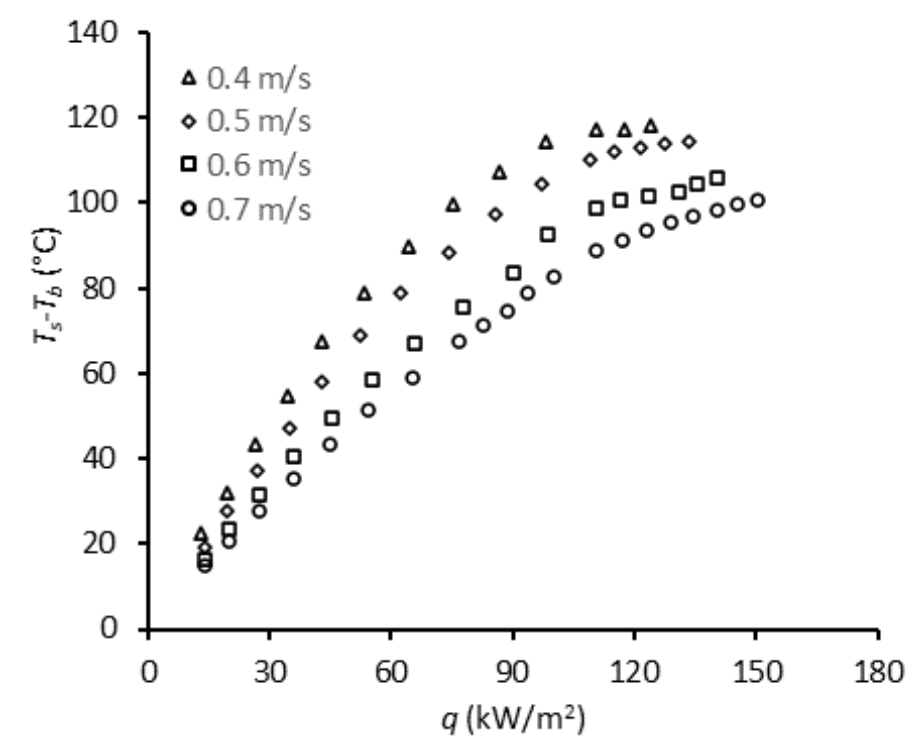

Fig. 5. Velocity effect on $q_{\max }$ and $\left(T_{s}-T_{b}\right)_{\max }$ for crude oil A at bulk temperature of $100^{\circ} \mathrm{C}$ and pressure of 50 bar

\subsection{Crude oil $B$}

\subsubsection{Effect of bulk temperatures}

Figure 6 and 7 show the boiling curves of crude oil B at $0.6 \mathrm{~m} / \mathrm{s}$ of velocity and 100, 120 and 140 ${ }^{\circ} \mathrm{C}$ of bulk temperatures. The slope is suddenly increased after the inception of nucleate boiling. The forced convective regime was ceased to exist beyond the limiting values of $\left(T_{s}-T_{b}\right)$ which were found to be $117.4,107.6$, and $80.3^{\circ} \mathrm{C}$ at bulk temperatures of 100,120 , and $140{ }^{\circ} \mathrm{C}$, respectively. The corresponding values of maximum heat flux are shown in Table 3. 


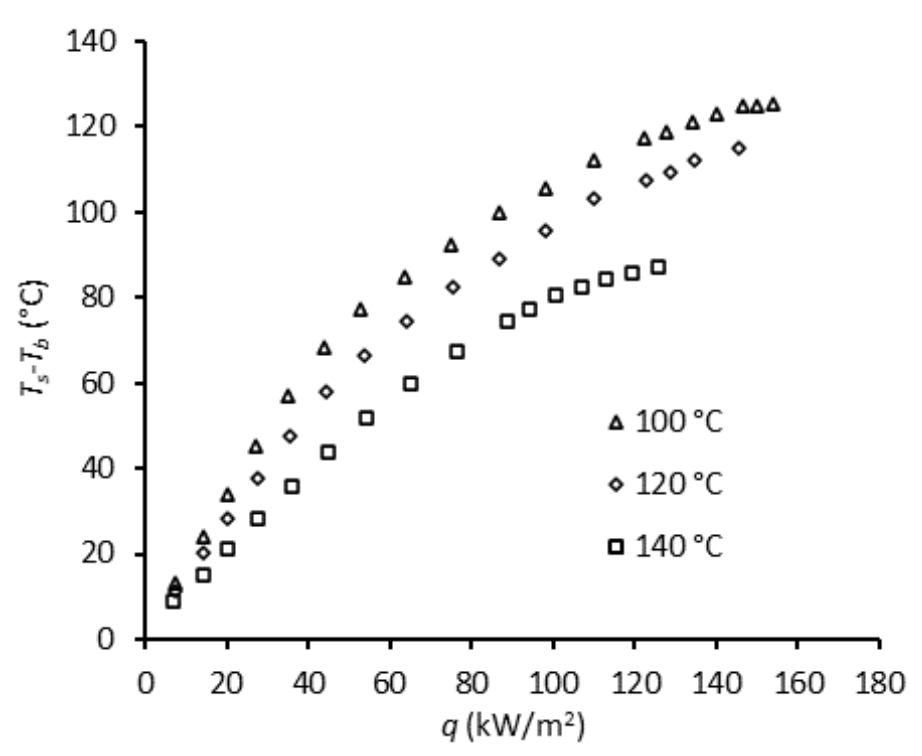

Fig. 6. Boiling curve to determine $q_{\max }$ and $\left(T_{s}-T_{b}\right)_{\max }$ at different bulk temperatures for crude oil $B$ at velocity of $0.6 \mathrm{~m} / \mathrm{s}$ and pressure of $50 \mathrm{bar}$

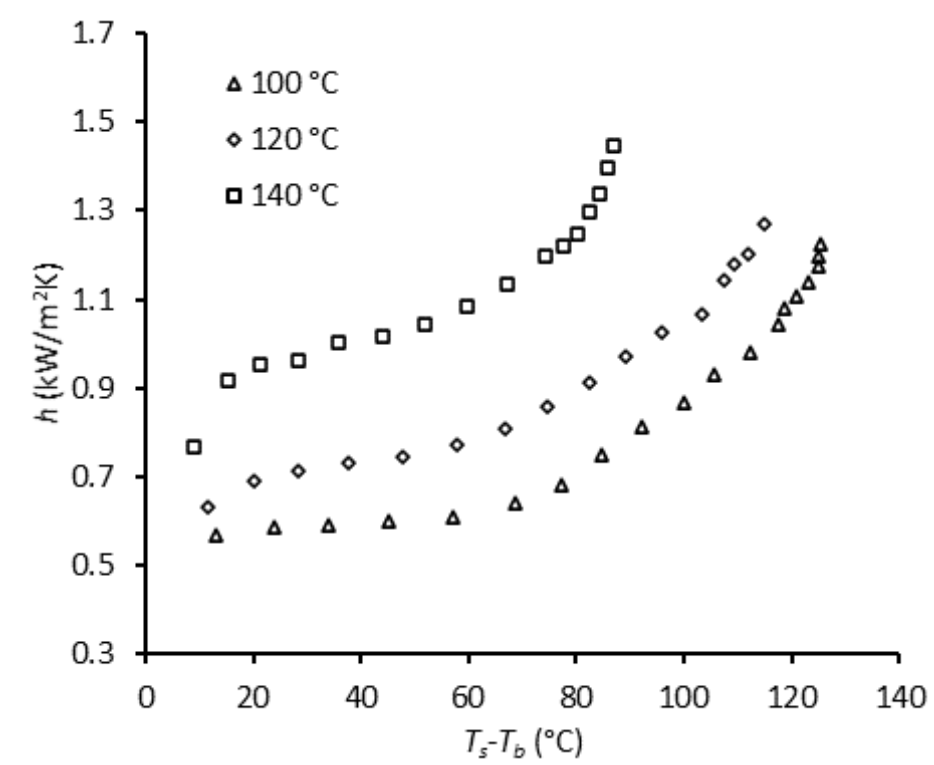

Fig. 7. Boiling curve to determine $h_{\max }$ at different bulk temperatures for crude oil B at velocity of $0.6 \mathrm{~m} / \mathrm{s}$ and pressure of 50 bar

\subsubsection{Effect of velocity}

The effect of velocity on the inception point of nucleate boiling for crude oil B was determined through boiling curves which were developed at different velocities such as $0.4,0.5,0.6$, and $0.7 \mathrm{~m} / \mathrm{s}$ and bulk temperature of $120^{\circ} \mathrm{C}$ as shown in Figure 8 and 9. The limiting values of $\left(T_{s}-T_{b}\right)$ were found to be $130.3,131.3,107.6$, and $100.3^{\circ} \mathrm{C}$ at $0.4,0.5,0.6$, and $0.7 \mathrm{~m} / \mathrm{s}$ of bulk velocities, respectively. The corresponding threshold values of heat flux were also determined from Figure 9. 


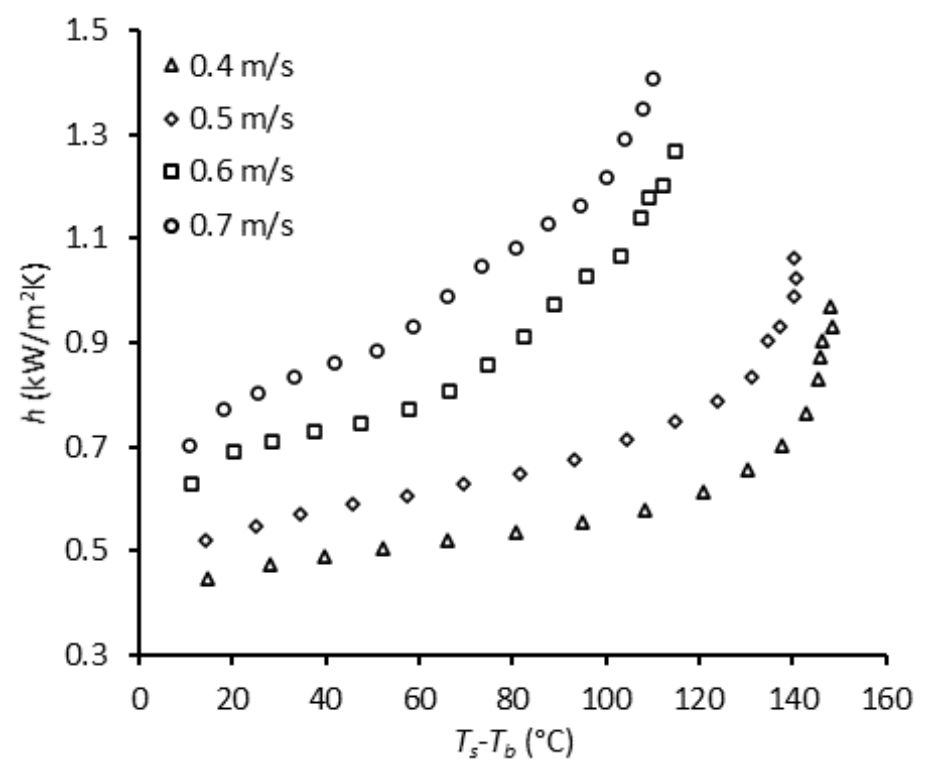

Fig. 8. Velocity effect on $h_{\max }$ for crude oil B at bulk temperature of $120^{\circ} \mathrm{C}$ and pressure of 50 bar

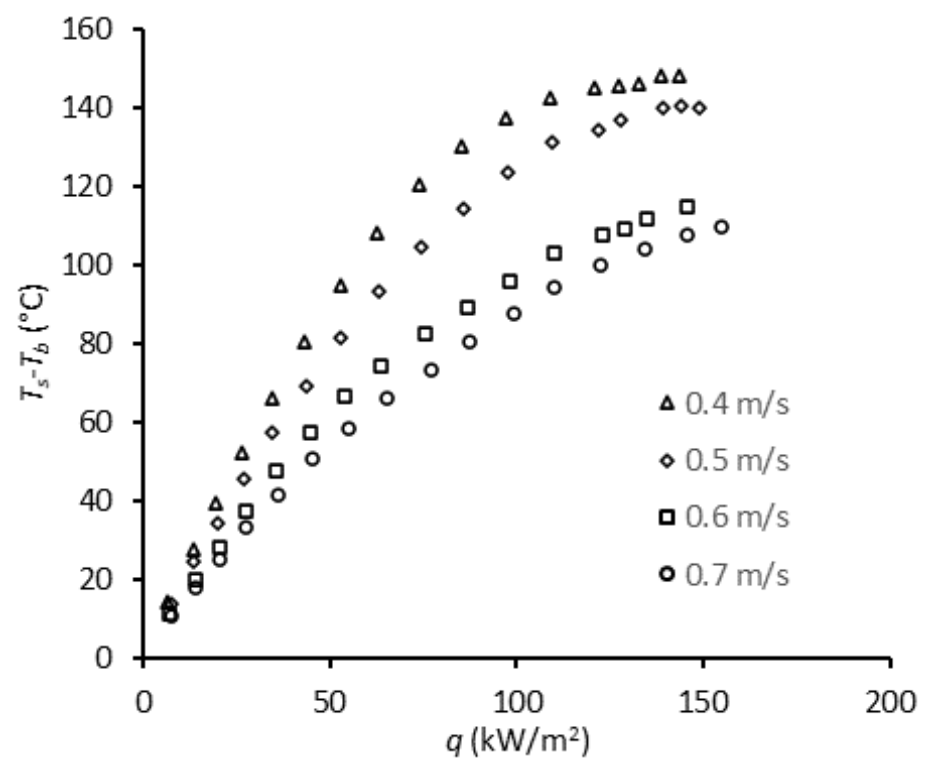

Fig. 9. Velocity effect on $q_{\max }$ and $\left(T_{s}-T_{b}\right)_{\max }$ for crude oil B at $\mathrm{T}_{\mathrm{b}}=120^{\circ} \mathrm{C}$ and $\mathrm{P}=50$ bar

\section{Discussion on Boiling Curves}

The boiling curves developed consist of two distinct regions i.e., forced convective and nucleate boiling regimes. In the first phase of forced convective heat transfer, the graphs of boiling curves showed a linear rise in $\left(T_{s}-T_{b}\right)$ with the heat flux. Similarly, the heat transfer coefficient was slightly increased with the heat flux which indicated the viscosity decline and increased turbulence resulted in improved heat transfer. The same phenomenon was elucidated by the rise in heat transfer coefficient with bulk temperatures. After the onset of nucleate boiling, the energy transferred did not contributed in the temperature rise which was depicted by the straight line in $q$ vs. $\left(T_{s}-T_{b}\right)$ graph.

The inception of nucleate boiling can also be related with the exponential increase of the heat transfer coefficient. The values of $\left(T_{s}-T_{b}\right)_{\max }, q_{\max }$, and $h_{\max }$ for all the runs below which forced convective heat transfer persisted for both crude oil A and B are presented in Table 3. 


\begin{tabular}{|c|c|c|c|c|c|c|c|}
\hline Run no. & Crude Oils & $\begin{array}{l}T_{b} \\
\left({ }^{\circ} \mathrm{C}\right)\end{array}$ & $\begin{array}{l}v \\
(\mathrm{~m} / \mathrm{s})\end{array}$ & $\begin{array}{l}q_{\max } \\
\left(\mathrm{kW} / \mathrm{m}^{2}\right)\end{array}$ & $\begin{array}{l}h_{\max } \\
\left(\mathrm{kW} / \mathrm{m}^{2} . \mathrm{K}\right)\end{array}$ & $\begin{array}{l}\left(T_{s}-T_{b}\right)_{\max } \\
\left({ }^{\circ} \mathrm{C}\right)\end{array}$ & $\begin{array}{l}T_{s, \max } \\
\left({ }^{\circ} \mathrm{C}\right)\end{array}$ \\
\hline 1 & \multirow{12}{*}{ A } & 100 & 0.4 & 75.1 & 0.754 & 99.6 & 199.6 \\
\hline 2 & & 100 & 0.5 & 85.4 & 0.8757 & 97.5 & 197.5 \\
\hline 3 & & 100 & 0.6 & 98.7 & 1.12 & 92.7 & 192.7 \\
\hline 4 & & 100 & 0.7 & 110.3 & 1.24 & 89 & 189 \\
\hline 5 & & 120 & 0.4 & 76.4 & 0.872 & 87.6 & 207.6 \\
\hline 6 & & 120 & 0.5 & 76.8 & 0.996 & 77 & 197 \\
\hline 7 & & 120 & 0.6 & 76.4 & 1.13 & 67.3 & 187.3 \\
\hline 8 & & 120 & 0.7 & 106 & 1.32 & 80.4 & 200.4 \\
\hline 9 & & 140 & 0.4 & 65.4 & 0.926 & 70.6 & 210.6 \\
\hline 10 & & 140 & 0.5 & 76.8 & 0.996 & 77 & 217 \\
\hline 11 & & 140 & 0.6 & 76.4 & 1.13 & 67.3 & 207.3 \\
\hline 12 & & 140 & 0.7 & 106 & 1.32 & 80.4 & 220.4 \\
\hline 13 & \multirow{12}{*}{ B } & 100 & 0.4 & 99.2 & 0.66 & 150.3 & 250.3 \\
\hline 14 & & 100 & 0.5 & 110 & 0.8 & 137.6 & 237.6 \\
\hline 15 & & 100 & 0.6 & 122.3 & 1.04 & 117.4 & 217.4 \\
\hline 16 & & 100 & 0.7 & 133.6 & 1.2 & 110 & 210 \\
\hline 17 & & 120 & 0.4 & 85.5 & 0.656 & 130 & 250 \\
\hline 18 & & 120 & 0.5 & 109.4 & 0.833 & 131.3 & 251.3 \\
\hline 19 & & 120 & 0.6 & 122.8 & 1.14 & 107.6 & 227.6 \\
\hline 20 & & 120 & 0.7 & 122.3 & 1.22 & 100.3 & 220.3 \\
\hline 21 & & 140 & 0.4 & 76.4 & 0.98 & 78 & 218 \\
\hline 22 & & 140 & 0.5 & 88.8 & 1.06 & 83.8 & 223.8 \\
\hline 23 & & 140 & 0.6 & 100.4 & 1.25 & 80.3 & 220.3 \\
\hline 24 & & 140 & 0.7 & 111.4 & 1.345 & 82.8 & 222.8 \\
\hline
\end{tabular}

\section{Prediction of Maximum Heat Flux}

The temperature values at 50 cumulative percentage of volume recovered were determined from the true boiling point distillation curves are $260{ }^{\circ} \mathrm{C}$ for crude oil $\mathrm{A}$ and $320^{\circ} \mathrm{C}$ for crude oil B. Heat transfer coefficients were determined using various equations such as Prandtl analogy ( $\left.h_{P A}\right)$, DittusBoelter $\left(h_{D B}\right)$, Sieder and Tate $\left(h_{S T}\right)$, Wiegand $\left(h_{W E}\right)$, and Gnielinski $\left(h_{G E}\right)$ correlations. The correlations are presented as follows

Prandtl analogy

$$
S t=\frac{\frac{f}{2}}{1+5 \sqrt{\frac{f}{2}}(\operatorname{Pr}-1)}
$$

Dittus-Boelter equation

$$
N u=0.023 \operatorname{Re}^{0.8} \operatorname{Pr}^{0.4}
$$

Sieder and Tate equation 
$N u=0.027 \operatorname{Re}^{0.8} \operatorname{Pr}^{\frac{1}{3}}\left(\mu / \mu_{w}\right)^{0.14}$

Wiegand correlation

$N u=0.023 a^{0.45} \operatorname{Re}^{0.8} \operatorname{Pr}^{\frac{1}{3}}\left(\mu / \mu_{w}\right)^{0.14}$

Gnielinski correlation

$$
N u=\frac{\left(\frac{f}{8}\right)(\operatorname{Re} 1000) \operatorname{Pr}}{1+12.7\left(\frac{f}{8}\right)^{\frac{1}{2}}\left(\operatorname{Pr}^{\frac{2}{3}}-1\right)}
$$

where St, $\mathrm{Nu}, \mathrm{Pr}$, and Re represent Stanton, Nusselt, Prandtl, and Reynolds numbers, respectively. Additionally, a represents the annular diameter ratio and the friction factor $(f)$ was estimated using the following equation as

$$
f=\frac{0.25}{\left[\log \left(\frac{1}{3.7\left(\frac{D e}{\epsilon}\right)}+\frac{5.74}{R e^{0.9}}\right)\right]^{2}}
$$

where $D e$ and $\in$ are effective diameter and pip roughness.

The maximum heat transfer coefficients were estimated using the above correlations. The sum of squares errors (SSE) for $h_{D B}, h_{S T}, h_{G E}$, and $h_{W E}$ were found to be $0.38,0.23,0.18$, and 0.29 , respectively. The best predictions were made by Gnielinski correlation as can be seen in Figure 10. Although Deshannavar and Ramasamy [21] suggested the Prandtl analogy to be more accurate to predict the heat transfer coefficient, it showed highest errors in present study.

The theoretical maximum flux was estimated using heat transfer coefficients predicted by Gnielinski correlation as shown below

$$
q_{\max }=h_{G E}\left(T_{b p 0.5}-T_{b}\right)
$$

The estimated theoretical and experimental $q_{\max }$ are compared in Figure 11 . The relative error values range from 31 to $115 \%$. Hence, the model needs to be updated to predict the maximum heat flux. 


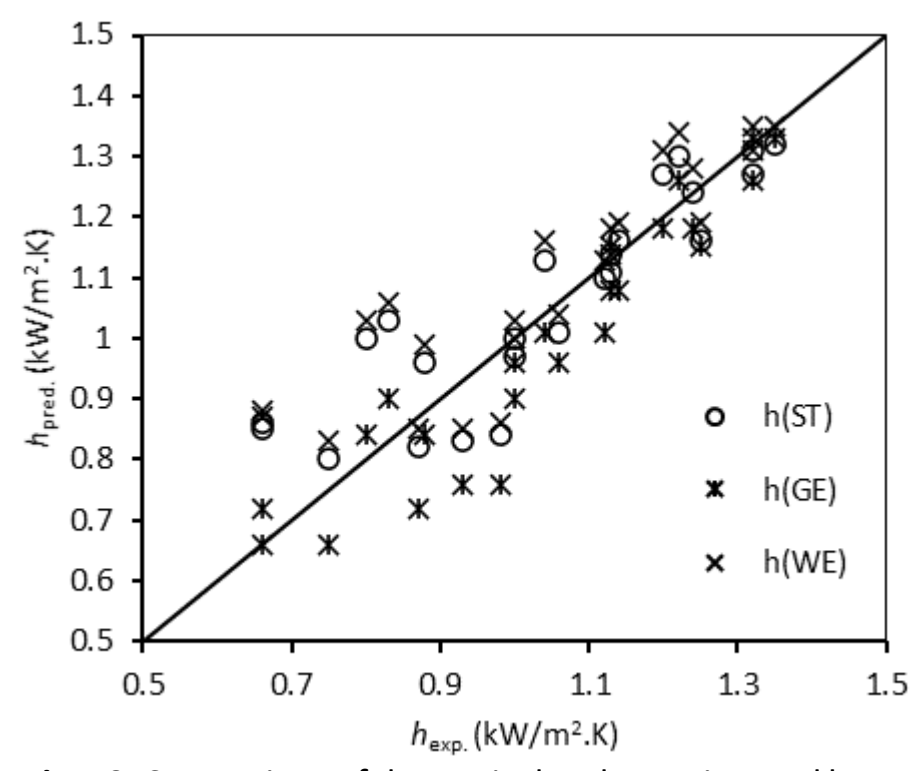

Fig. 10. Comparison of theoretical and experimental heat transfer coefficients, $\mathrm{kW} / \mathrm{m}^{2} \cdot \mathrm{K}$

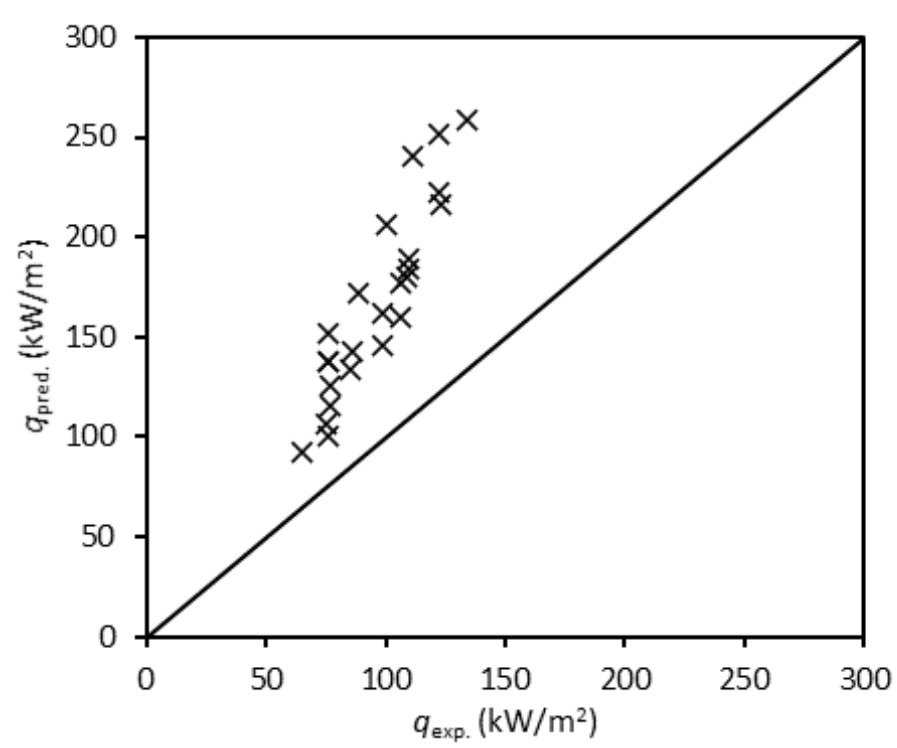

Fig. 11. Comparison of theoretical and experimental maximum heat flux $\left(q_{\max }\right), \mathrm{kW} / \mathrm{m}^{2}$

\section{Conclusions}

The accuracy of fouling experimental results highly depends on the heat transfer regime. Boiling can contribute to significant errors in the estimation fouling rate. In order to carry out the fouling experiments, it is highly recommended to predetermine the maximum heat flux below which forced convective regime exists. In this study, two crude oils were tested for maximum heat flux in forced convective regimes at different operating conditions. The results suggest that the maximum heat transfer coefficient increased with increasing bulk temperature which indicate a decrease in crude oil viscosity as temperature rises and an increase in turbulence which promoted heat transfer. The velocity effects were similar to bulk temperature effects as increasing both led to the increased requirement of heat flux for similar surface temperatures. The model was found to be inadequate to 
predict maximum heat flux specially for the crude oils studied. It is concluded that the study to find the maximum heat flux should essentially be carried out through experiments.

\section{Acknowledgment}

This work is supported by the Chemical Engineering Department of Universiti Teknologi PETRONAS. The financial assistance is provided by Yayasan UTP (Grant No. 015LC0-130).

\section{References}

[1] Tahreen, Amina, and Mohammed Saedi Jami. "Advances in Antifouling Strategies in Membrane Ultrafiltration: A Brief Review." Journal of Advanced Research in Materials Science 76, no. 1 (2021): 10-16. https://doi.org/10.37934/arms.76.1.1016

[2] Hagsten, Carin, Fredrik Innings, Christian Trägårdh, Lars Hamberg, Marie Paulsson, and Tommy Nylander. "Removal of UHT dairy fouling-An efficient cleaning process by optimizing the rate controlling alkaline cleaning step." Food and bioproducts processing 113 (2019): 101-107. https://doi.org/10.1016/j.fbp.2018.11.010

[3] Ebert, W., and C. B. Panchal. Analysis of Exxon crude-oil-slip stream coking data. No. ANL/ES/CP-92175; CONF9506406-3. Argonne National Lab., IL (United States), 1995.

[4] Polley, Graham T., D. I. Wilson, B. L. Yeap, and S. J. Pugh. "Evaluation of laboratory crude oil threshold fouling data for application to refinery pre-heat trains." Applied Thermal Engineering 22, no. 7 (2002): 777-788. https://doi.org/10.1016/S1359-4311(02)00023-6

[5] Nasr, Mohammad Reza Jafari, and Mehdi Majidi Givi. "Modeling of crude oil fouling in preheat exchangers of refinery distillation units." Applied thermal engineering 26, no. 14-15 (2006): $1572-1577$. https://doi.org/10.1016/j.applthermaleng.2005.12.001

[6] Shetty, Nitin, Umesh Basanagouda Deshannavar, Ramasamy Marappagounder, and Rajashekhar Pendyala. "Improved threshold fouling models for crude oils." Energy 111 (2016): $453-467$. https://doi.org/10.1016/i.energy.2016.05.130

[7] Panchal, C. "Threshold conditions for crude oil fouling. Understanding Heat Exchanger Fouling and its Mitigation," UEF." (1999): 273-281.

[8] Crittenden, B. D., S. T. Kolaczkowski, and S. A. Hout. "Modelling hydrocarbon fouling." Chemical engineering research \& design 65, no. 2 (1987): 171-179.

[9] Eaton, P., and R. Lux. "Laboratory fouling test apparatus for hydrocarbon feedstocks." ASME HTD 35, no. 1 (1984): 33-42.

[10] Petkovic, Bojan, and Paul Watkinson. "Fouling of a heated rod in a stirred tank system." Heat transfer engineering 35, no. 3 (2014): 302-310. https://doi.org/10.1080/01457632.2013.825191

[11] Yang, M., A. O'meara, and B. D. Crittenden. "Determination of crude oil fouling thresholds." In Proc. of International Conference on Heat Exchanger Fouling and Cleaning-June, pp. 05-10. 2011.

[12] Crittenden, Barry D., Stanislaw T. Kolaczkowski, T. Takemoto, and D. Z. Phillips. "Crude oil fouling in a pilot-scale parallel tube apparatus." Heat Transfer Engineering 30, no. $10-11 \quad$ (2009): $777-785$. https://doi.org/10.1080/01457630902744135

[13] Wilson, D. I., R. C. Lai, and A. P. Watkinson. "Model Experiments of Autoxidation Reaction Fouling. 2. Effect of Flow Parameters and Antioxidants." Chemical engineering research \& design 73, no. 1 (1995): 69-77.

[14] Saleh, Zaid S., R. Sheikholeslami, and A. P. Watkinson. "Fouling characteristics of a light Australian crude oil." Heat transfer engineering 26, no. 1 (2005): 15-22. https://doi.org/10.1080/01457630590890049

[15] Sahak, Ahmad Sofianuddin A., Nor Azwadi Che Sidik, and Siti Nurul Akmal Yusof. "A Brief Review of Particle Dispersion of Cavity Flow." Journal of Advanced Research in Applied Sciences and Engineering Technology 20, no. 1 (2020): 27-41. https://doi.org/10.37934/araset.20.1.2741

[16] Harris, Jonathan S., Matthew R. Lane, and Aaron D. Smith. "Investigating the impact of boiling conditions on the fouling of a crude oil." Heat Transfer Engineering 38, no. 7-8 (2017): $703-711$. https://doi.org/10.1080/01457632.2016.1206411

[17] Fetissoff, P.E., Watkinson, A. Paul., Epstein, Norman. "Comparison of Two Heat Transfer Fouling Probes." In Proceedings of the 7th International Heat Transfer Conference, 1982, (1982): 391-396. https://doi.org/10.1615/IHTC7.2550

[18] Crittenden, B. D., and E. M. H. Khater. "Fouling from vaporizing kerosine." (1987): 583-589." Journal of Heat Transfer 109, no. 3, (1987): 583-589. https://doi.org/10.1115/1.3248128

[19] Ishiyama, Edward M., and Simon J. Pugh. "Considering in-tube crude oil boiling in assessing performance of preheat trains subject to fouling." Heat Transfer Engineering 36, no. 7-8 (2015): 632-641. 
https://doi.org/10.1080/01457632.2015.954916

[20] Hariis, J. "The Interpretation of Data From a Stirred Batch Cell." University of Bath, 2014.

[21] Deshannavar, Umesh B., and M. Ramasamy. "A model to determine maximum heat flux under forced convective heat transfer regime for crude oil fouling studies." Applied Thermal Engineering 156 (2019): 485-493. https://doi.org/10.1016/i.applthermaleng.2019.04.091

[22] Ghiasi, Pedram, Amar Salehi, Seyed Salar Hoseini, Gholamhassan Najafi, Rizalman Mamat, Balkhaya Balkhaya, and Fitri Khoerunnisa. "Investigation of the Effect of Flow Rate on Fluid Heat Transfer in Counter-Flow Helical Heat Exchanger Using CFD Method." CFD Letters 12, no. 3 (2020): 98-111. https://doi.org/10.37934/cfdl.12.3.98111 